\title{
A New Layer in a World Heritage Site: The Post-War Reconstruction of Mostar's Historic Core
}

\author{
Dünya Mirası Alanında Yeni Bir Katman: Mostar Tarihi Kent Merkezinin \\ Savaş Sonrası Yeniden Yapılandırılması
}

\author{
Mehmet Bengü ULUENGIN, ${ }^{1}$ Öze ULUENGiN²
}

\section{ABSTRACT}

This paper focuses on the historic core of Mostar in general, and the Old Bridge in particular, and attempts to trace this city's unique experience to rebuild and revitalize itself after a particularly destructive series of armed conflicts. Just as its preservation before the war was exemplary, Mostar's destruction during the painful dissolution of the Yugoslav Federation proved to be an example of human destruction at its worst. The city's devastation became a symbol of backwardness and ethnic strife in the Balkans. The destruction of the Old Bridge, in turn, came to be regarded as an attack on a multi-cultural Bosnia in general, and Mostar in particular with its Ottoman, Mediterranean and western-European architectural features. Mostar's postwar situation, particularly as it pertains to the city's architectural heritage, is considerably more complex than what many interpretations would have us believe. It seems that Mostar's (and by extension, Bosnia's) multiculturalism can be better understood if one accepts that some antagonism is necessarily present in any multicultural society. Indeed, greater insight into cities such as Mostar would be gained if they are taken not as sites of "positive tolerance" but those of "competitive sharing and antagonistic tolerance." Methodologically, the study takes a panoptic view of numerous local and international institutions' efforts, and evaluates them based on the expectations and exigencies of local residents. The article's conclusions are articulated at several different, but interrelated levels: implications regarding the local populace, implications for cities that may have issues similar to that of Mostar, and lastly, implications for disciplines which focus on issues of urban regeneration, housing renovation, and the revitalization of old neighborhoods.

Keywords: Bosnia and Herzegovina; Mostar; Old Bridge; reconstruction; urban preservation.

\section{ÖZ}

Bu makale, genel olarak, Bosna-Hersek'teki Mostar kentinin tarihi kent dokusunu ve özellikle Mostar Köprüsü'nü irdelemekte ve bir dizi silahlı çatışmanın yıkıcı etkisinin ardından, bu kente özgün yeniden yapılanma ve yeniden canlanma deneyiminin izlerini sürmeye çalışmaktadır. Savaş öncesi dönemde, Mostar'da gerçekleştirilen koruma çalışmalarının örnek niteliği taşıması gibi; Yugoslavya Federasyonu'nun sancılı bir şekilde dağılmasının ardından kentin yıkımı da, insan tahribatının ne kadar ileri seviyelere varabileceğini kanıtlamış ve kentteki tahribat, Balkanlar'daki geri kalmışlığın ve etnik anlaşmazlığın bir sembolü haline gelmiştir. Mostar Köprüsü'nde gerçekleştirilen yıkım, genel olarak Bosna ve Osmanlı, Akdeniz ve Batı Avrupa özellikleri taşıyan Mostar'daki çok kültürlülüğe bir saldırı olarak kabul edilmiştir. Mostar'ın savaş sonrası durumu, özellikle de kentin mimari mirası ile doğrudan ilgili olduğu için, pek çok yorumda belirtildiğinden çok daha karmaşıktır. Mostar'ın (dolayısıyla Bosna-Hersek'in) çok kültürlülügüünün anlaşılması, bu tür toplumlarda karşıt görüşlerin temsil edilmesinin gerekliliğinin kabul edilmesiyle gerçekleşebilir. Aslında, Mostar gibi kentleri daha iyi kavramak, bu kentlerin 'pozitif tolerans' bölgelerindense 'rekabetçi paylaşım ve karşıt tolerans' bölgeleri olarak kavranmasıyla mümkün olacaktır. Yöntembilimsel olarak çalışma, genel bir bakış açısıyla çok sayıda yerel ve uluslararası kurumun çabalarını yansıtmakta ve bunları yerel halkın beklenti ve ihtiyaçları doğrultusunda geliştirmeyi hedeflemektedir. Makalenin sonucu birkaç farklı, fakat birbiriyle ilgili düzeyde ortaya konmuştur: Bunlar, yerel halkın neden olacağı olası sonuçlar, Mostar ile benzer özellikler gösteren kentler için olası sonuçlar ve son olarak, kentsel canlandırma, konut yenileme ve eski mahallelerin yeniden canlandırılması konularına odaklanmış disiplinler için olası sonuçlardır.

Anahtar sözcükler: Bosna-Hersek; Mostar; Mostar Köprüsü; yeniden yapılandırma; kentsel koruma. 


\section{Introduction}

For those involved in historic preservation, the City of Mostar in Bosnia and Herzegovina is an invaluable case study. In the late 1970s and early 1980s, Mostar was a shining example of what could be achieved through the loyal application of historic preservation principles and prudent management. It was a city with a well-preserved, lively, and economically viable historic core; the city's overall modest size had ensured that the center was not overrun by automobile traffic; and the city had managed to preserve and stay integrated with its unique natural heritage. Furthermore, the city was model for what Yugoslavia should be: an exemplary mix of the three main ethnic groups-Bosnians, Serbs and Croats - that made up the Federation.

But, people seldom let the built environment be. The spaces we inhabit are made, and unmade; they are designed, and redesigned; they are painstakingly put up, only to be torn down. In tinkering with the built environment, people's motives are not always practical ones, such as making it more fit for habitation. Built environments are often manipulated, sometimes even annihilated, to alter the narrative that emerges thence. Indeed, the destruction of built environments because of the stories they tell-referred to as 'urbicide' of late-is as old as history itself. As Chusid ${ }^{1}$ aptly states, "from the smallest element of a site to the whole-scale destruction of cities to acts of genocide, rewriting history is ever present, in ways both subtle and obvious".

Regardless, the post-colonial, post-modern, and-in the particular case at hand-the post-Soviet era has witnessed a marked increase in efforts to alter the built environment. From Buddhist monuments in Afghanistan to the Old Bridge in Mostar, the world has experienced a crescendo of efforts to destroy the built-and particularly historic-environments of 'other cultures'. The response to such 'identity politics' has been, and continues to be, stereotypical and usually oversimplified. And neither are such shortcomings limited to 'popular' or public media. Even in academia, incongruous constructs such as the 'Clash of Civilizations' thesis can be found. ${ }^{2}$

This is certainly true of Mostar. Just as its preservation was exemplary, Mostar's destruction during the painful dissolution of the Yugoslav Federation proved to be an example of human destruction at its worst. The city's devastation became a symbol of backwardness and ethnic strife in the Balkans. ${ }^{3}$ The destruction

1 Chusid, 2000, p. 8.

Grodach, 2010, p. 62

2 For example: Huntington, 1993.

of the Old Bridge, in turn, came to be regarded as an attack on a multi-cultural Bosnia in general, and Mostar in particular.

In response to such identity politics, increasing efforts to reassert 'other cultures' surfaced, most notably in the form of rebuilding physical environments that were destroyed to deny the culture's existence in the first place. Perhaps the most famous case of such reassertion is the post-World War II reconstruction of the medieval walled centre of Warsaw, but the recent reconstruction of the Old Bridge in Mostar (Figure 1) may, in time, become a more salient example. Thus, long after the fighting ended, the conflict continued on the 'architectural front'.

This paper focuses on the historic core of Mostar in general, and the Old Bridge in particular at this particular juncture, and attempts to trace this city's unique experience in rebuilding and reconstructing itself after a particularly destructive series of armed conflicts. The case is made all the more salient due to the destruction of the city's main symbol-the Old Bridge, or, as referred to locally, Stari Most. Indeed, as the Aga-Khan-Award-laureate architect Amir Pašić states, "Without this bridge, Mostar no longer exists. It has no hope, no meaning". ${ }^{4}$

\section{The Historic Context}

Mostar means 'bridge-keeper', ${ }^{5}$ and this makes the city's origins amply clear: the city flourished around a wooden bridge built in 1452 over the Neretva River. This bridge opened a westward route on the ancient road that followed the river's eastern shore, and which linked the Adriatic and the Danube. The Ottomans, who conquered Herzegovina in 1463, inherited this valuable crossing, and designated Mostar as the region's administrative centre. To consolidate and advertise their presence, the new rulers initiated a rapid building program including mosques, 'hamams' (Turkish baths) and 'hans' (inns for traveling merchants). This growth both necessitated, and was fueled by, the replacement of the wooden bridge. The new stone bridge (completed in 1567) solidified Mostar as the centre of Herzegovina, and spawned more investment in the city's physical and cultural infrastructure. Thus, by the end of the seventeenth century, Mostar's social space and urban fabric was rendered predominantly Ottoman/Islamic.

Despite their avowed attachment to Islam, how-

${ }^{4}$ Quoted in Dodds, 1998, p. 49.

5 The word "Stari Most" has the meaning of "old bridge", Chapman, 1994; Petrovic, 2012, p.62. 


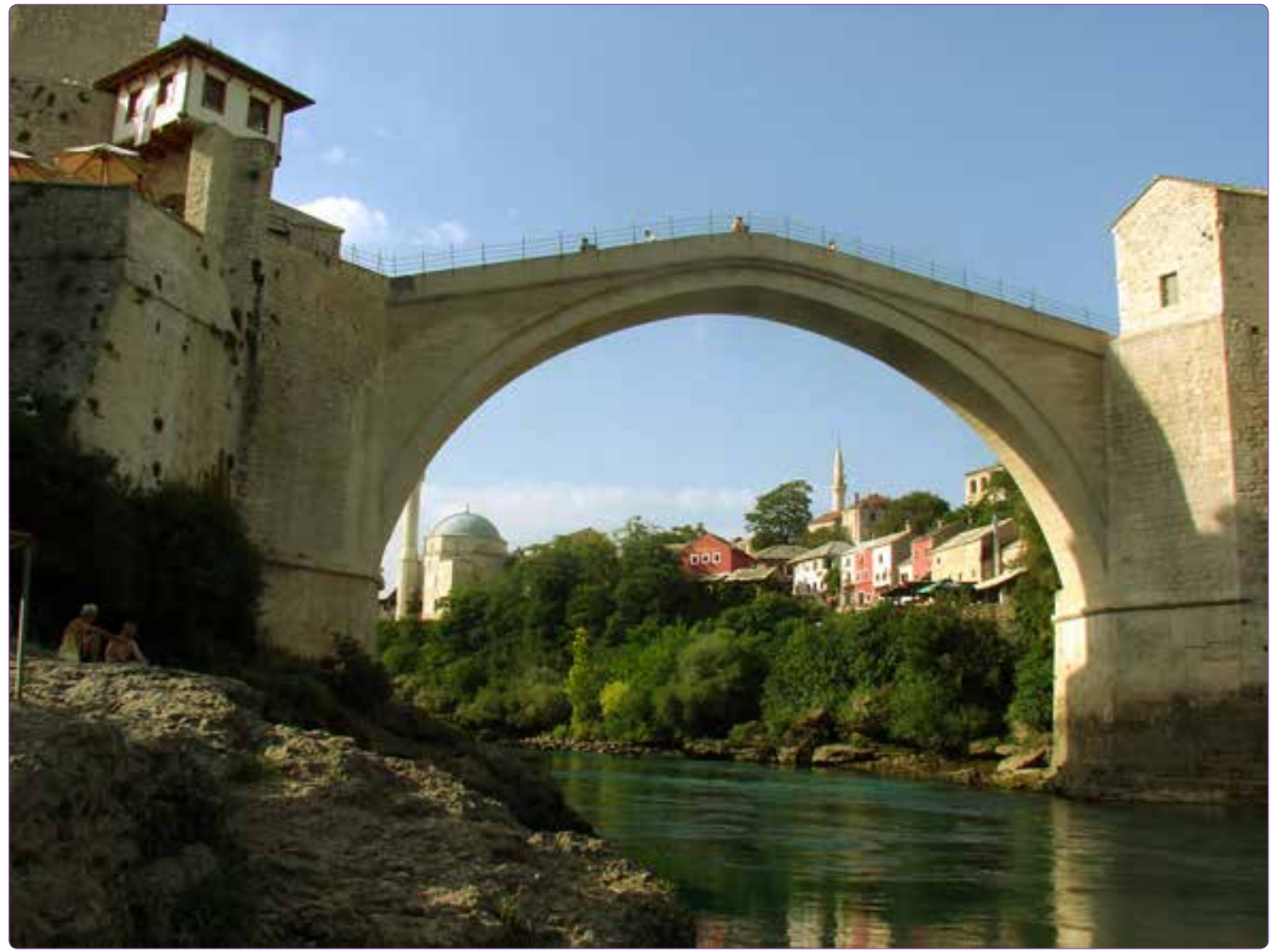

Figure 1. Old Bridge in Mostar. Photo: Şenol Demir.

ever, Ottoman rulers did not force their non-Muslim subjects to convert. Per their 'millet' system of administration, the Ottomans permitted adherents of monotheistic creeds to maintain their respective religious practices and social customs. ${ }^{6}$ Under Ottoman rule, Bosnian Serbs and Croats, who retained their Orthodox and Catholic creeds respectively, rubbed shoulders with those who had converted to Islam.

By the eighteenth century, however, Ottoman dominance in the Balkans came under increasing challenge, and as Ottoman control waned, Western influence waxed. Finally, in 1878, the Ottomans ceded Herzegovina to the Habsburgs.

The takeover fueled another era of frenzied growth. Eager to tap into Herzegovina's mineral riches, the Habsburgs constructed a railroad linking Mostar both to Central Europe and the Adriatic. Investment in the city's infrastructure also increased exponentially. With its new districts of tree-lined boulevards, Mostar's expansion continued up until the World War I.

The end of World War I also saw the end of Habsburg

\footnotetext{
6 Braude, 1982; Brown, 1996.
}

rule in Herzegovina. In the inter-war period, Herzegovina was largely neglected under the Yugoslavian Kingdom, as national attention was focused on Serbian and Croatian rivalry. With World War II, these rivalries quickly turned into civil war, resulting in a bitter series of aggressions. By the end of the war, an estimated one million war-deaths marred Yugoslavia's history.

For three decades following World War II, Yugoslavia enjoyed a period of relative peace and prosperity under Josip Broz Tito's communist government. Memories of prior conflicts were firmly suppressed and all Yugoslavs were united under the banner of Federal Yugoslavia.

Yet suppression alone cannot erase memories of the past. Warmongers of the 1990s used memories of World War II to incite the ethnic conflicts of the recent war. In Mostar, clashes between the JHA (the Yugoslavian military, largely controlled by the Serbs), the HVO (the Bosnian Croatian Nationalist Party) and Bosnian Muslim forces, left many parts of the city in ruins. But the most intense fighting occurred on the frontline formed by the Bulevar Narodne Revolucije-commonly referred to as 'the Bulevar' - which divided the city 


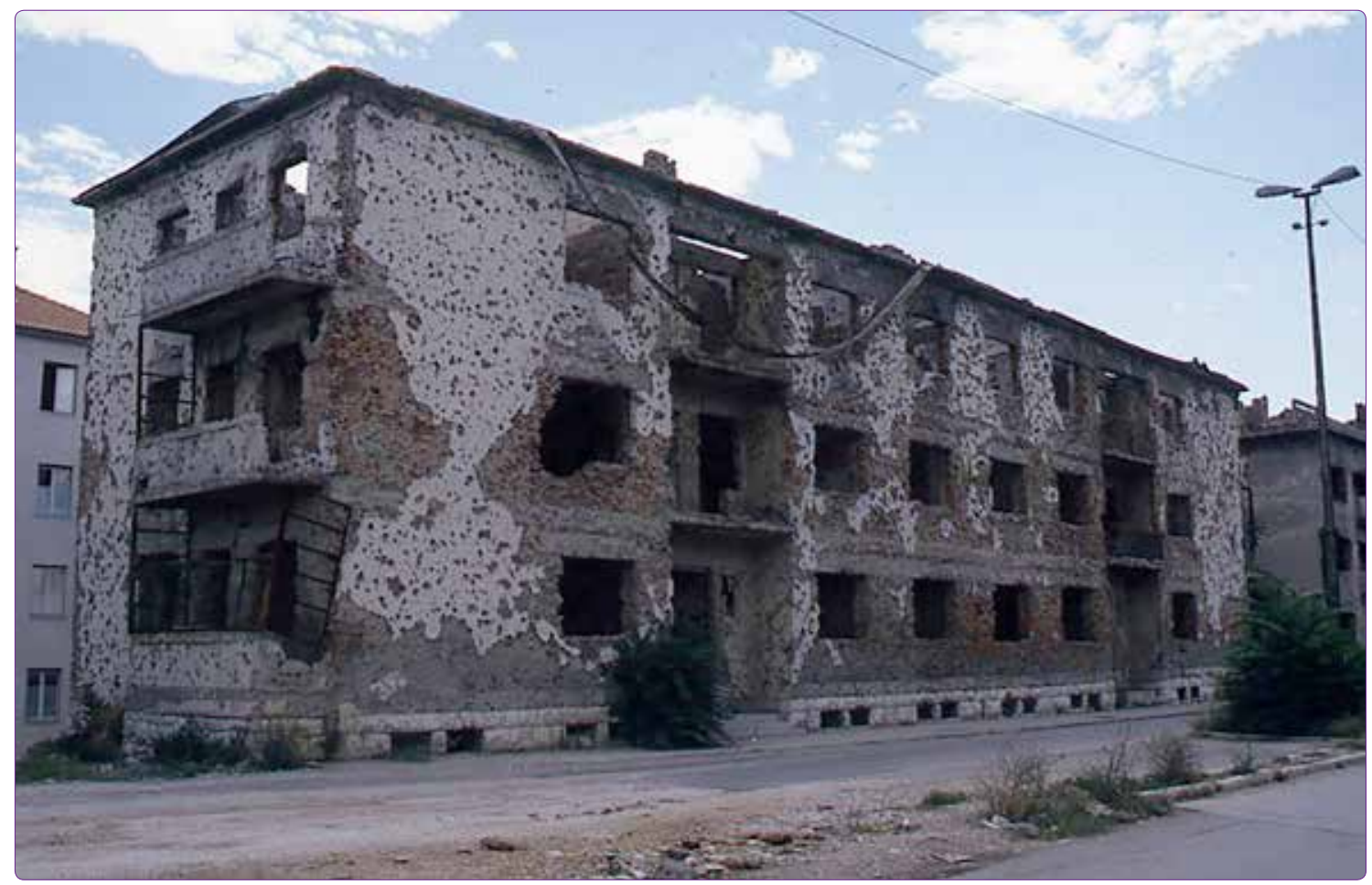

Figure 2. The Bulevar. Photo: Bengü Uluengin.

into the Muslim-controlled east and Croat-controlled west (Figure 2). Contrary to popular imagination outside Herzegovina, the Neretva River did not form the city's line of division.

Mostar's division along the Bulevar became a symbol of seemingly irreconcilable ethnic differences throughout former Yugoslavia. While it is true that the destruction of the city's Old Bridge was the most symbolic act of violence, thrusting, as it did, Mostar into public awareness world over, the city's division along the Bulevar affected the lives of Mostarians most acutely. This was because the greater portion of Mostar's housing stock was-and still is-in the Croatiancontrolled west; thus, the division left many Muslim families displaced. Furthermore, the strip of bombedout buildings along both sides of the Bulevar continues to present a public hazard, as well as an eyesore.

Yet Mostar is not a divided city in the sense that Berlin or Nicosia were-there is no wall separating the two sides; neither is there barbed wire or soldiers with machine guns. Furthermore, the strips of land on either side of the Bulevar have witnessed intense building activity in the post-war period. Part of this building activity, obviously, is to undo the devastating effects of the war and to reconstruct these war-torn quarters. But the nature of the building activities cannot be explained as mere reconstruction. There is much more at stake. These construction activities coincide, naturally, with a period when the newly established states try to establish their identity and to distance themselves from their recent enemies with whom, in fact, they share a much greater common past then they would care to admit.

Such identity politics heavily influence what gets built in Mostar and where it gets built. This has caused the conflict in Mostar to continue on the "architectural front" for much longer than the armed conflict itself.

\section{Yugoslav Identity}

A broader look, at this point, at what nationalism is and how its forces have played out in former Yugoslavia is deemed appropriate. Our interpretation of nationalism is based on the Gellnerian construct of nations and nation-making. Gellner ${ }^{7}$ argues that nations are born of nationalist movements, not the other way around. That is, naturally occurring nations do not become nationalistic; rather, national movements create nations. As such, the concept of nation has no stable set of referents (as opposed to other categories of identity such as race, class, kinship, sex or language) and can only be explained in terms of these and similar variables. Thus, among other forms of identity, national affiliation is 
particularly abstract and fluid. Historic events such as the breakup of Yugoslavia dramatically alter national identities which are often formed in direct contrast with other groups. As the perceived "other" changes, so does the concept of 'nation'.

Throughout history the particular case at hand, i.e. Bosnia, seems to have managed these shifts in perception of nationhood very well. Indeed, many would argue that Bosnia has a strong pluralistic tradition (whether real or imagined). ${ }^{8}$ Our view, however, is that the unity of Mostar's, and by extension Bosnia's, peoples was a tenuous one. Like the identical poles of two magnets being forced together, there is a distinct tension to the unity of Bosnia. Beginning with the 'millet $^{\prime 9}$ system during Ottoman rule, different religious groups lived together, but fairly autonomously in Bosnia. A similar decentralization existed under Federal Yugoslavia, with largely autonomous republics being organized around a general socialist idea. Even the recent government set up by the Dayton Peace Accords in 1995 brings together "autonomous entities" this time amalgamated by mandate of the international community.

Regardless, "Common to all Balkan nations is the self-perception of being at the crossroads of civilizational contacts, of having the character of a bridge between cultures". ${ }^{10}$ This 'bridge metaphor' was a particularly strong one in Bosnia. As Gunzburger aptly summarizes, Bosnia is the meeting place for different religions (Christianity and Islam); for Eastern and Western Christianity (the fourth-century division of the Roman Empire passes through it); and for different economic systems ('liaises faire' versus command economies). "Bosnia is also a regional or geographic bridge between Europe and Asia, or Europe and the Near East. Even climatically Bosnia bridges continental and Mediterranean Europe and the divide between the Adriatic and Black Sea tributaries are found in its mountains". ${ }^{11}$

Furthermore, when Bosnia is described as a bridge, the connotation is almost always positive, because a pluralistic society with a tradition of cultural coexistence is considered good. This positive valuation is also influenced by the Yugoslav ideal and arguments for the unity of the south Slavs in the nineteenth and twentieth centuries. But this argument found strong

\footnotetext{
Matvejevic, 1993, p. 16.

9 'Millet' is an Ottoman Turkish term which refers to confes-

sional communities in the Otto-

man Empire and the word millet

comes from the Arabic word mil-

lah and literally means nation.

(Kaya, 2013).

Todorova, 1997, p. 57-58.

1 Gunzburger, 2001, p. 4.
}

support mainly because the alternative was foreign domination (be it Ottoman and Austro-Hungarian, or German and Italian). In the present case, however, "... multicultural Bosnia is argued in opposition to either partition into separate autonomous entities or union of the Bosnian Serbs with Serbia and Bosnian Croats with Croatia". ${ }^{12}$ This creates a considerably more untenable situation, with many of the key players opposed to the idea of a multinational Bosnia: most Bosnian Croats and Bosnian Serbs feel stronger affiliation to Croatia and Serbia than to Bosnia. Further complicating matters is the argument made by some that the Muslims are trying to dominate Bosnia and attempting to project the image of an Islamic country. ${ }^{13}$ This is certainly a critical issue, as we saw above, when the reconstruction of Mostar's historic core is concerned, since most of the buildings in the city center date from the Ottoman period. Thus, as the city center is rebuilt and reconstructed Mostar reflects an increasingly Ottoman and hence Islamic image, leading to increased tension between the city's factions.

\section{The Architectural Front}

Mostar had been heavily impacted by the war in 1990's, which destroyed its bridge and damaged the historic center, with its Ottoman, Mediterranean and western-European architectural features. ${ }^{14}$ After the fighting was over the Mostar's people vowed to rebuild the city and its monuments. The reconstruction of the historical bridge and its surroundings is the symbol of the combined endeavors of all rebuild-attempts. ${ }^{15}$

The first appeal for reconstruction was launched by UNESCO in 1994 and the government requested the World Bank's to provide assistance to rebuild the bridge. The object of the project, known as Pilot Cultural Heritage Project was more than rebuild the bridge. The hope was to improve the reconciliation process among Bosnia and Herzegovinas people. ${ }^{16}$

The ethnoreligious groups of Mostar have adopted a building program that solidifies and, indeed, intensifies Mostar's division. The years following cease-fire have witnessed an accelerating building program on either side of the artificial border, whereby the respective ethno-religious populations assert their (anticipated) permanence. This is not unique phenomenon in and of itself. The post-World War II reconstruction

\footnotetext{
12 Gunzburger, 2001, p. 2.

${ }^{13}$ Anonymous, 1996 (New Republic).

${ }^{14}$ Cameron, 2008, p.22.

${ }^{15}$ Armaly, Blasi and Hannah, 2004,
}

p.14.

${ }^{16}$ The restoration of national monuments in Bosnia and Herzegovina became an important component of the 1995 Dayton Peace Accords, which ended the war. 


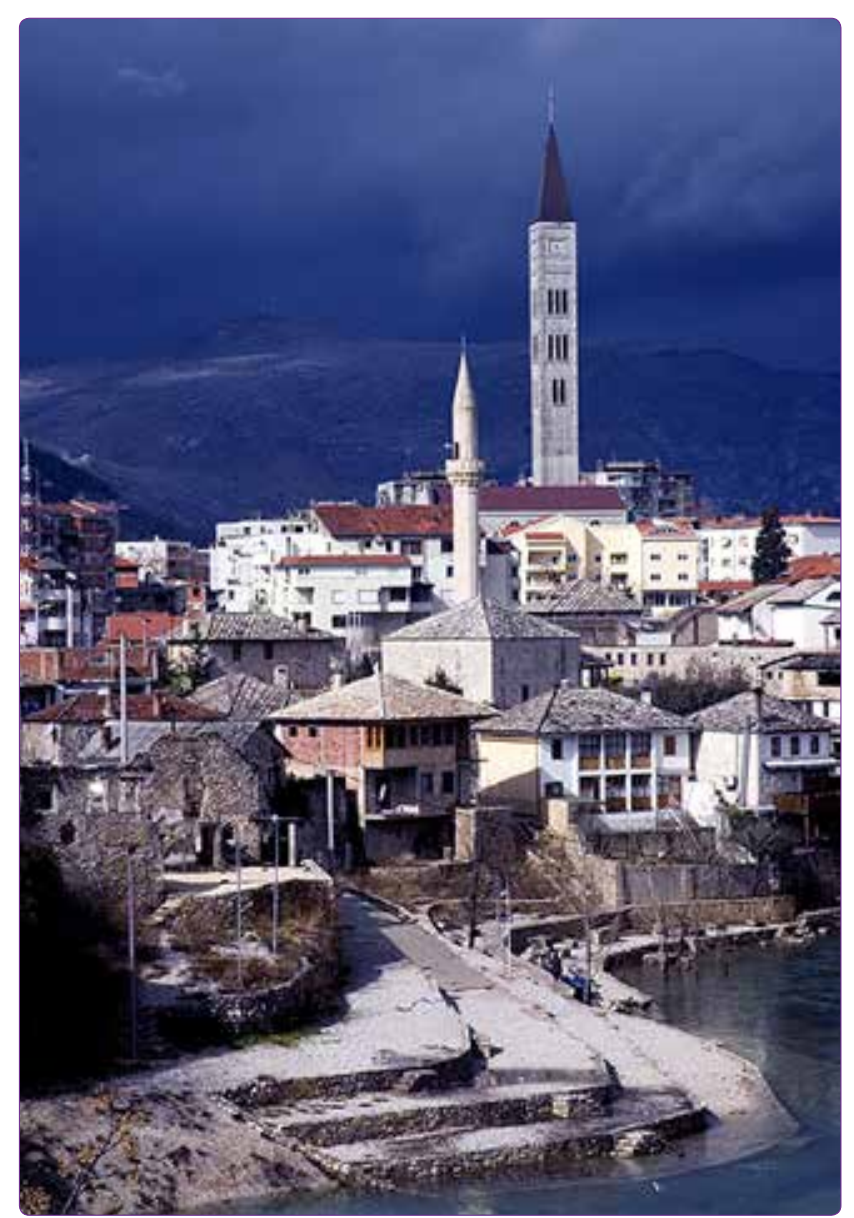

Figure 3. The Neziraga Mosque with the Franciscan Church's spire in the distance. Photo: Robert Roadstar.

of East and West Berlin also witnessed similar moves. But the intensity with which such identity politics are played out in the architectural arena in Mostar, and the complex layering of meanings that this "silent conflict" spawns are truly unique.

As part of this building program, for example, the Franciscan Church (Figure 3) slightly west of the Bulevar was rebuilt, being enlarged more than three times in the process. The church's disproportionately-tall concrete spire looms over the city and its bells chime every fifteen minutes, audible quite far into the Muslim part of the city.

Countering this is the Neziraga Mosque located in the Spile quarter, immediately on the Muslim side of the Bulevar. Built in 1550, the mosque was one of the oldest in Mostar. It even predated the Old Bridge. It enjoyed a sizable congregation before it was closed to prayers in 1932, and subsequently demolished by the Yugoslav Communist Party in 1950. Because the site was not redeveloped, however, the mosque's ruins were preserved: as of the end of the Bosnian War, roughly a foot of perimeter wall was visible above the earth, with the base of the minaret just discernable.

As part of its efforts to reconstruct Mostar's historic core, the Research Centre for Islamic History, Art and Culture (IRCICA; based in Istanbul, Turkey) initiated a project for the mosque's reconstruction. Funding was secured through Sheikh Salim Al-Qasimi, Emir of Sharjah (United Arab Emirates), and the reconstructed mosque was inaugurated in 1999. With the very active rebuilding agenda in Mostar however, it takes conscious effort to remember that the Neziraga Mosque was not destroyed during the recent war, but forty-five years before. When there are other historic sites of arguably greater significance, why does the reconstruction of a mosque-long-gone become an issue at this time?

The reason put forth by Ekmeleddin Ihsanoğlu, then-director of IRCICA, in his inauguration speech ${ }^{17}$ was that the cultural discrimination of Bosnian Muslims had been an ongoing issue which started well before the recent war. The war was simply a culmination of the ill-treatment Bosnian Muslims endured since World War II. Starting the rebuilding process with a monument that was destroyed at the outset of this discriminative period signified, in Ihsanoğlu's view, Bosnian Muslims' desire to "reclaim their whole past-to undo all of the injustice done to their community". The inquiring mind, however, can also find other reasons. As well as having a visual presence with its minaret, the mosque is able to cast prayer calls over the Croatian side five times a day, thus countering the Franciscan Church.

But perhaps the most notorious post-war project in Mostar is the thirty-three-meter Jubilee Cross on Hum Hill (Figure 4), erected in 2000 by Mostar's Bishop. The choice of location for the cross is particularly salient, because it happens to be the same spot that both the JHA (the Yugoslavian military, largely controlled by the Serbs), and the HVO (the Bosnian Croatian Nationalist Party) shelled the city, killing and injuring hundreds of its citizens. During the war, controlling Hum Hill meant controlling Mostar. The Cross, then, comes forth as a statement of victory for the city's Croat Catholics.

And then, of course, there is the Old Bridge. Just as its destruction was seen as an attack on a multicultural Mostar, its reconstruction was taken to symbolize reconciliation in the city. With the rebuilding of the bridge, the different factions were to "burry their hatchets," and continue living together as they did

\footnotetext{
${ }^{17}$ Author's notes from inauguration speech.
} 


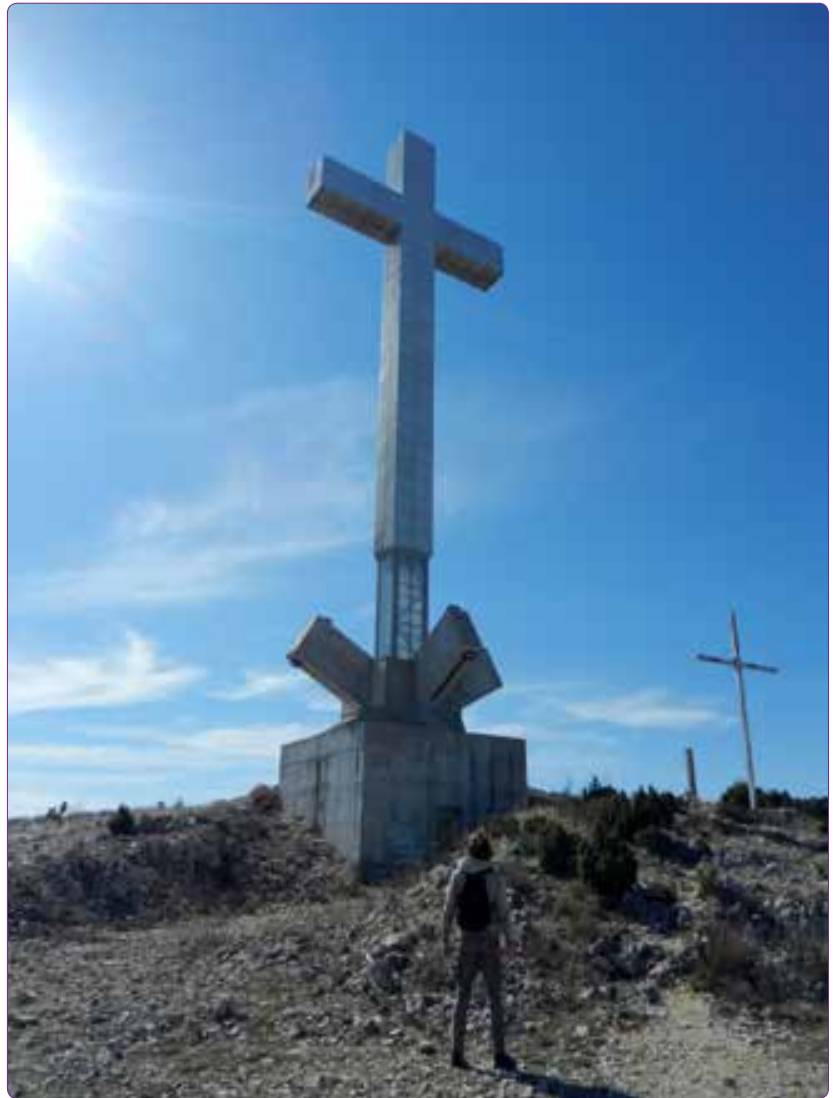

Figure 4. The thirty-three-meter Jubilee Cross on Hum Hill, Photo: Ashleigh Westphal*

before. Within this framework of tolerance, Mostar's economy was to flourish, aided by funds from foreign organizations such as the World Bank and cash infusion provided by tourists. ${ }^{18}$ It was the aim of the former to rebuild the social, physical, and financial infrastructure of Mostar, while the infusion of the latter depended on the aforementioned efforts. Thus, particular attention was paid to the rebuilding of historic buildings. These buildings, in turn, were to act as anchors for a rejuvenated tourist economy.

Or so the international community thought. But much of Mostar's physical fabric, most notably the historic buildings in the city's core, are from the Ottoman period (including the Old Bridge). Restoring these buildings and reconstructing the city's core enhances the city's Ottoman, and hence Islamic, image. Thus, such activities serve to increase antagonism between the different factions of the city, and contribute to the solidification of the architectural front.

Due to the strong symbolisms associated with the Old Bridge, it was during the reconstruction of this monument that these antagonisms came forth most forcefully. From the very beginning, the reconstruction of the bridge was a very multi-national effort. Funding was secured through a loan by the World Bank, as well as donations from numerous states, including the Netherlands, France, Italy, the European Union, Turkey, and Croatia. The companies involved in the actual reconstruction were likewise representative of a large number of nations. Further, the international community took great care to ensure that all factions in the city-Muslims, Croats, and Serbs-were part of the reconstruction process. Cooperation between Mostar's residents, however, remained far below international expectations. The majority of the city's Croats-including those in the city's administration-were either apathetic towards, or openly opposed to the reconstruction process. This opposition consisted mainly of minor actions aimed at delaying the process, such as failing to show up at meetings. But occasionally, it included more serious acts of sabotage. To recount one example, in July 2000 during international efforts to retrieve the submerged stones of the Old Bridge from the Neterva River, Bosnian Croat authorities opened floodgates further upstream and managed to inundate a mobile crane that had been lowered to the riverside. The crane operator barely managed to flee to higher ground.

Mostar's Croat population is also opposed to the new layers of meanings attached to the Old Bridge in the past decade. They do not see the bridge as a symbol of reconciliation, but simply as a symbol of Mostar. Thus, they revert to its pre-war meaning so as to remain attached to a symbol which they feel increasingly alienated from.

But regardless of such controversies, since the end of the Bosnian War, various international NGOs (such as IRCICA, the Aga Khan Trust for Culture and the World Monuments Fund) have invested substantially in the reconstruction of historic Mostar. These NGOs have played key roles in establishing an urban regeneration scheme and undertaking individual restoration projects to help revitalize the urban fabric in the historic core of Mostar in general, and around the Old Bridge in particular.

Perhaps the most comprehensive planning and reconstruction efforts taken in post-war Mostar were the joint efforts of the Aga Khan Trust for Culture (AKTC) and the World Monuments Fund (WMF). As part of these efforts, the joint AKTC/WMF technical team: ${ }^{19}$ 


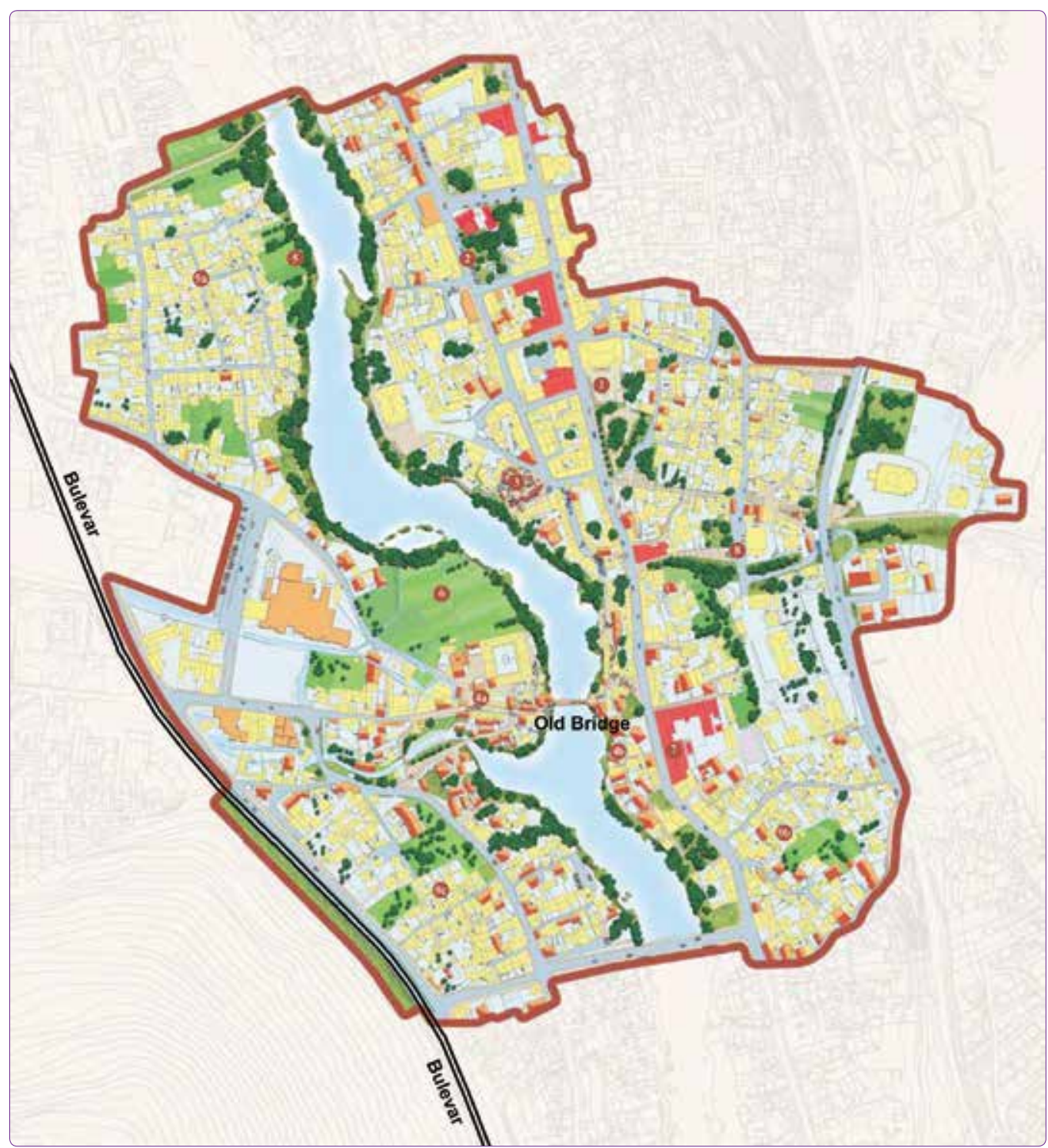

Figure 5. Old Town Conservation and Development Area. AKTC/WMF.**

...began in 1998 the preparation of a Conservation and Development Plan for the Old Town. This plan was formally adopted by the authorities on 15 May 2001. It includes plans, regulations and guidelines for the protection of the historic core of Mostar, detailed proposals for the rehabilitation of the neighborhood areas, and a series of adaptive re-use schemes for priority buildings, as well as provisions to support institutional strengthening and active management of the historic city's future.

Siravo further claims that "planning work ... continued in the nineteenth-century parts of the city, adjacent to the Old Town," in an effort to "...integrate the central area with the rest of Mostar and put in place the conditions needed to establish a cohesive plan for the entire city". ${ }^{20}$ But a scrutiny of plan documents (Figure 5) reveals that planning efforts were concentrated on East Mostar in their entirety (despite the presence of a substantial amount of urban fabric from the nineteenth century in West Mostar). The "priority buildings" motioned above are also mostly in East Mostar (Figure 6), although here, the claim that these "include Catholic, Orthodox and Muslim religious structures; Ottoman, Austro-Hungarian, and Socialist-era public buildings; as well as important commercial, residential and educational buildings," rings more true. While the majority of buildings on this list (nine of twenty two buildings) is from the Ottoman period (and/or belong to the Islamic community) the list does contain build-

\footnotetext{
** Siravo, 2004, p. 22-23. $\quad{ }^{20}$ Siravo, 2004, p. 13.
} 


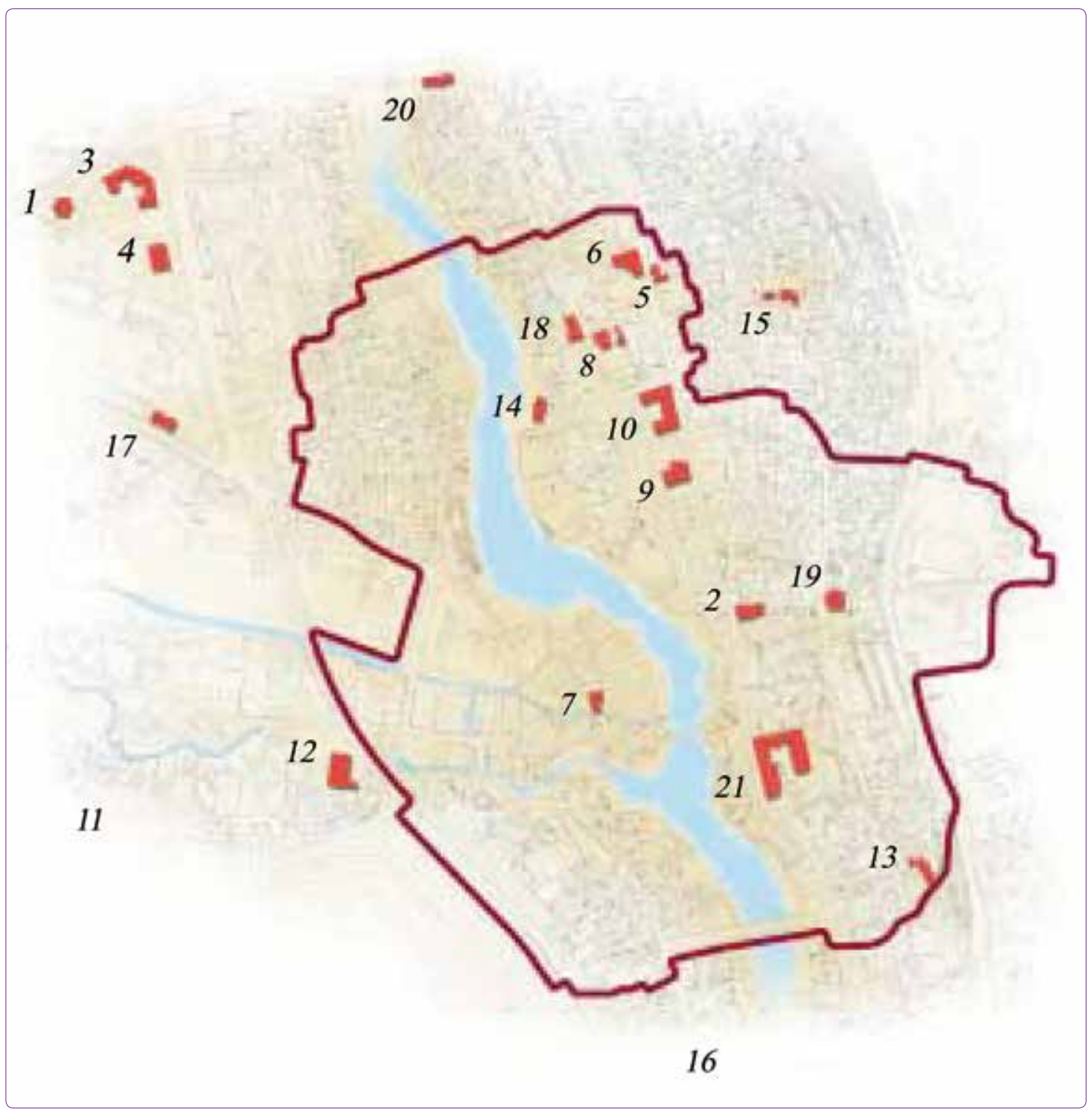

Figure 6. Priority Buildings For Intervention. AKTC/WMF.***

ings from the Austro-Hungarian and Socialist periods. Additionally, all religious groups are represented.

Not all of these buildings have been restored, but three buildings restored using funds made available by the World Bank are significant. The project to restore these buildings was dubbed, "Three Nations" s'nce the buildings selected-Croat Cultural Center Napredak, the Serbian Orthodox Metropolitan's Palace, and the Islamic Community's Vakuf Palace-were representative of the three communities resident in Mostar. As Gunzburger ${ }^{21}$ notes, "This separate but equal treatment reflects the general trend among governmental and non-governmental European and American

\footnotetext{
***Pašić and Siravo, 2004, p. 47-56. $\quad{ }^{21}$ Gunzburger, 2007, p. 327.
}

based donors to Bosnia's postwar reconstruction," yet "by singling out sites and associating them with distinct groups within the Bosnian population, this kind of 'three nation' initiative can also be understood as highlighting their separation".

Scores of other institutions have undertaken other, smaller scale interventions in Mostar to undo most of the damage that the previous war had wrought on the city. Indeed, barring the odd pock-marked building, there are relatively few signs of the war in Mostar. In view of this fact, UNESCO added the Old Bridge and its vicinity to the World Heritage List in July 2005. Before the Bosnian War, Mostar was a city renowned for its rich historic heritage. In 1986 Stari-Grad won the Aga Khan Award for Architecture in recognition of the exemplary 
manner in which this rehabilitation was handled. Thus, Mostar has seemingly gone full circle, from being international heritage site to war zone, and back again.

\section{Conclusion}

Mostar's postwar situation, particularly as it pertains to the city's architectural heritage, is considerably more complex than what many interpretations would have us believe. Among the most simplistic of interpretations is perhaps that of the international community's. As Michael Ignatieff ${ }^{22}$ notes, Bosnia was Europe and America's foremost nation-building experiment in the 1990s, and since the conflict had dragged on for long enough, there could be nothing better than a beautiful bridge to mark the end of hostilities and to symbolize reconciliation. But did the Old Bridge (or, for that matter, the efforts to rebuild the historic core) really reconcile? The evidence seems to suggest otherwise. Indeed, even the most unifying projects such as the rebuilding of the Old Bridge can be seen as divisive due to the controversies that they spawned.

Moreover, the assumption that Mostar has gone full circle from being international heritage site to war zone, must be questioned. Does not city's historic heritage-termed "dissonant heritage" by some ${ }^{23}$-now convey a different message? Is the simplistic message conveyed UNESCO's decision-that things have gone back to the way they were-adequate? I would argue otherwise. Contemporary historic preservation theory teaches us that all historic layers present in a heritage site must be respected (and indeed celebrated), and cities are no exception. Thus, the Bulevar-and the way it has become an architectural front following the cessation of armed hostilities-is part of Mostar's history, and must be honored. So long as the Bulevar is not an actual division line (which it no longer is: the city's ethnic factions now freely cross it), the narrative that emerges thence should not be shunned.

Even such controversial projects such as the Franciscan Church and the Jubilee Cross can be interpreted differently if the Croat perspective is considered: in a setting where Mostar is becoming increasingly Islamic (according to Croat perception), these symbols reflect Croat fears that their identity is being lost in a community where they are the minority. It seems that Mostar's (and by extension, Bosnia's) multiculturalism can be better understood if one accepts that some antagonism is necessarily present in any multicultural society. Indeed, as anthropologist Robert Hayden ${ }^{24}$

\footnotetext{
22 2003. $\quad{ }^{23}$ see Ashworth and Tunbridge, 1996. $\quad{ }^{24}$ 2002, p. 217.
}

has argued, greater insight into cities such as Mostar would be gained if they are taken not as sites of "positive tolerence" but those of "competitive sharing and antagonistic tolerance".

Thus Mostar may come to symbolize the new coexistence that now characterizes Bosnia and Herzegovina. This is no less, and no more tenuous than prior amalgamations of the region's peoples, and fully reflects the complicated, dualistic nature of conflict and harmony prevalent in their society.

\section{References}

Anonymous, (1996) "What is Bosnia?" New Republic (20 May), pages not numbered.

Armaly, M., Blasi, C. and Hannah, L. (2004) "Stari Most: Rebuilding More Than a Historic Bridge in Mostar", Museum International, No. 224, Vol: 56, No:4. pp.7-17.

Ashworth, G. and Tunbridge, J. E. (1996) Dissonant Heritage: The Management of the Past as a Resource in Conflict, John Wiley and Sons, New York.

Braude, B. (1982) "Foundation Myths of the Millet System" The Christians and Jews in the Ottoman Empire: the Functioning of a Plural Society, Volume 1: The Central Lands, Ed.: B. Braude and B. Lewis, Holmes \& Meier Publishers, Inc, New York and London, p. 69-88.

Brown, L. C. (ed.), (1996) Imperial Legacy: The Ottoman Imprint on the Balkans and the Middle East, Columbia University Press, New York.

Cameron, C. (2008) "From Warsaw to Mostar: The World Heritage Committee and Authenticity", APT Bulletin, Vol. 39, No. 2/3 pp.19-24.

Chapman, J. (1994) "Destruction of a common heritage: the archaeology of war in Croatia, Bosnia and Hercegovina" Antiquity, Vol 68:258, pp 120-126.

Chusid, J. M. (2000) "The Mostar Studio: Research in Cultural Exchange and Conflict" Platform (Fall issue), p. 8-11.

Dodds, J. D. (1998) "Bridge over the Neretva" Archaeology 51/1, p. 48-53.

Gellner, E. (1983) Nations and Nationalism, Cornell University Press, Ithaca.

Grodach, C. (2010) "Reconstituting Identity and History in Post-War Mostar, Bosnia-Herzegovina" City v6/1, p. 6182.

Gunzburger, E. (2001) "Representing Multinational Bosnian Identity: The Bridge Metaphor and Mostar's Stari Most" Con/De/Recon-struction of South Slavic Architecture (available online at http://www.emilymakas.com/files/ PDFs/Makas_Metaphor.pdf).

Gunzburger, E. (2007) Representing Competing Identities: Building and Rebuilding in Postwar Mostar, unpublished dissertation submitted to the Department of Architecture, Cornell University.

Hayden, R. (2002) "Antagonistic Tolerance: Competitive Sharing of Religious Sites in South Asia and the Balkans" Current Anthropology 43/2, p. 205-231.

Huntington, S. P. (1993) "The Clash of Civilizations" Foreign 
Affairs, 72/3: p. 22-49.

Ignatieff, M. (2003) "Nation-Building (Mostar)," 60 Minutes, CBS, October 19, 2003, http://www.cbsnews.com/ stories/2003/10/17/60minutes/main578648.shtml.

Kaya, A. (2013) "Multiculturalism: The Culturalisation of What is Social and Political", Perceptions, Autumn 2013, Volume XVIII, Number 3, p. 63-91.

Matvejevic, P. (1993) "Old Bridges, Old Values" War Report (December), p. 16.

Pašić, A. (2006) Historic Reconstruction of the Neziraga Mosque Complex in Mostar, Bosnia and Herzegovina, Research Centre for Islamic History, Art and Culture, Istanbul.
Pašić, A. and Siravo, F. (2004) "Reclaiming Mostar's Monuments and Buildings" Conservation and Revitalisation of Historic Mostar, Aga Khan Trust for Culture, Geneva, p. 13-30.

Petrovic, J. (2012) The Old Bridge of Mostar and Increasing Respect for Cultural Property in Armed Conflict, Martinus Nijhoff Publishers.

Siravo, F. (2004) "Reintegrating the Old City" Conservation and Revitalisation of Historic Mostar, Aga Khan Trust for Culture, Geneva, p. 13-30.

Todorova, M. (1997) Imagining the Balkans, Oxford University Press, New York, p. 57-58. 